\title{
PENGARUH MODEL PEMBELAJARAN PROBLEM BASED LEARNING BERBANTUAN PENILAIAN PROYEK TERHADAP KOMPETENSI PENGETAHUAN PKn
}

\author{
Ni Wayan Yuli Arianti ${ }^{1}$, I.G.A.Agung Sri Asri ${ }^{2}$, I Wayan Wiarta ${ }^{3}$ \\ 1,2,3 Jurusan Pendidikan Guru Sekolah Dasar, FIP \\ Universitas Pendidikan Ganesha \\ Singaraja, Indonesia \\ email : yuli arianti@undiksha.ac.id ${ }^{1}$, igaagungsri.asri@undiksha.ac.id ${ }^{2}$, \\ iwayan.wiarta@undiksha.ac.id ${ }^{3}$
}

\begin{abstract}
Abstrak
Penelitian ini bertujuan untuk mengetahui perbedaan yang signifikan Kompetensi Pengetahun PKn antara siswa yang belajar melalui model pembelajaran Problem Based Learning berbantuan Penilaian proyek dengan siswa yang belajar secara konvensional di kelas IV SD Gugus VI Tegallalang Tahun Pelajaran 2012/2013. Jenis penelitian ini adalah penelitian eksperimen semu, dengan desain Nonequivalent Control Group Design. Populasi penelitian ini adalah siswa kelas IV SD Gugus VI Tegallalang yang berjumlah 165 orang. Penarikan sampel dalam penelitian ini menggunakan teknik random sampling dengan pengacakan kelas yang sudah ada dengan, kemudian dilakukan pengundian untuk penentuan kelompok eksperiment dan control sehingga diperoleh kelas IV SD Negeri 2 Keliki dengan jumlah 31 siswa sebagai kelompok eksperimen dan kelas IV SD Negeri 1 Keliki dengan jumlah 31 siswa sebagai kelompok kontrol. Data tentang kompetensi pengetahuan PKn dikumpulkan dengan menggunakan tes objektif bentuk pilihan ganda biasa sebanyak 35 soal yang sudah divalidasi. Selanjutnya data dianalisis dengan uji-t. Berdasarkan hasil analisis menyatakan tidak terdapat perbedaan yang signifikan kompetensi pengetahuan PKn antara siswa yang dibelajar melalui model pembelajaran Problem Based Learning berbantuan penilaian proyek dengan siswa yang belajar secara konvensional. Rata-rata kompetensi pengetahuan PKn kelompok eksperiment dan kelompok kontrol adalah $\bar{X}=83,02>\bar{X}=73,09$. Berdasarkan hasil penelitian tersebut dapat disimpulkan bahwa model pembelajaran Problem Based Learning berbantuan penilaian proyek berpengaruh terhadap Kompetensi Pengetahuan PKn siswa kelas IV SD Gugus VI Tegallalang.
\end{abstract}

Kata kunci: PBL, Penilain Proyek, PKn

\begin{abstract}
This research aimed to know the significant difference between PKn Knowledge Competence of students who learn through Problem Based Learning assisted Assessment project as a source of learning with students studying in conventional fourth grader at SD Cluster VI Tegallalang in 2012/2013 academic year. This type of research was quasi experimental research with Nonequivalent Control Group Design. The population of this research was the fourth grader at SD Negeri 2 Keliki Cluster VI Tegallalang tthat amount to 165 students. This study used random sampling techniques that randomize with existing classes, then conducted the draw for the determination of the group of alphabets experiment and control so that the retrieved fourth grader at SD Negeri 2 Keliki amount to 31 students as a group of experiments and forth grader at SD Negeri 1 Keliki with 31 students as the control group. Data about the competence of the knowledge collected by using test PKn objective multiple choices form usual as much as 35 reserved already validated. Further data analyzed by $t$-test. Based on the results of there was no significant difference between the PKn knowledge competence of students through Problem Based Learning-assisted assessment project with students who learned conventionally. Average knowledge competence group PKn alphabets experiment and control groups $83.02>=i s=73.09$. Based on the results of the study it can be concluded that Problem Based Learning-assisted assessment of project impact Knowledge Competence PKn fourth grader SD Cluster VI Tegallalang.
\end{abstract}

Keywords: PBL, Project Evaluation, PKn

Journal for Lesson and Learning Studies | 370 


\section{Pendahuluan}

Menurut Undang-undang Pendidikan Nasional tujuan pendidikan dijelaskan sebagai pengembangan potensi peserta didik agar menjadi manusia yang beriman dan bertaqwa Kepada Tuhan Yang Maha Esa, berakhlak mulia, sehat, berilmu, cekap, kretif, mandiri, dan menjadi warga Negara yang demokratis serta bertanggung jawab. Tujuan pendidikan nasional yang telah dipaparkan sejalan dengan visi pendidikan nasional yaitu terwujudya sistem pendidikan sebagai pranata sosial yang kuat dan berwibawa untuk memberdayakan semua warga Indonesia berkembang menjadi manusia yang berkualitas sehingga mampu dan proaktif untuk menghadapi tantangan zaman yang selalu berubah-ubah. Agar dapat mewujudkan tujuan pendidikan nasional maka disusunlah sebuah rencana tertulis yang di kenal dengan kurikulum. Kurikulum dalam Undang-undang Nomor 20 Tahun 2003 tentang Sistem Pendidikan Nasional dinyatakan "sebagai seperangkat rencana dan pengaturan tujuan, isi, dan bahan pelajaran serta cara yang digunakan sebagai pedoman penyelenggaraan kegiatan pembelajaran untuk mencapai tujuan pendidikan tertentu". Penyempurnaan kurikulum terus di lakukan pemerintah agar kualitas pendidikan bisa lebih maju. Sementara rangkainan penyempurnaan kurikulum terus dilakukan diantaranya, pada tahun 2004 dirintis Kurikulum Berbasis Kopentesi, kemudian diteruskan dengan kurikulum 2006 (KTSP) dan sekarang telah ditetapkan Kurikulum 2013.

Permendikbud Nomor 57 Tahun 2014 Lampiran 1 dinyatakan Kurikulum 2013 bertujuan untuk mempersiapkan manusia Indonesia agar memiliki kemampuan hidup sebagai pribadi dan warga negara yang beriman, produktif, kreaktif, inovatif dan evektif serta mampu berkontribusi pada kehidupan bermasyarakat, berbangsa dan bernegara. Dengan demikian, maka dapat disimpulkan bahwa kurikulum sebagai pedoman penyelenggaraan untuk mencapai tujuan pendididikan tertentu. Dengan demikian, dapat dipahami bahwa kurikulum sebagai pedoman penyelenggaraan kegiatan pembelajaran memegang peran penting dalam mengarahkan pembelajaran agar dapat mencapai tujuan pendidikan tertentu. Pentingnya keberadaan kurikulum dalam menunjang proses pembelajaran meyakinkan pemerintah untuk terus mengupayakan agar kurikulum yang berlaku pada setiap satuan pendidikan di indonesia dapat mengikuti dinamika perkembangan dunia global yang semakin pesat, sehingga bangsa Indonesia dapat menjadi bangsa yang cerdas dan tetap dapat bersaing secara internasional. Pada kurikulum 2013 siswa dituntut melalui beberapa proses secara aktif mencari, mengolah, mengontruksi, dan menerapkan pengetahuan, kurikulum lebih menekankan kepada kompetensi sikap, keterampilan, dan pengetahuan melalui sebuah pendekatan yang dikenal dengan pendekatan saintifik.

Model yang sesuai dengan pendekatan santifik adalah model pembelajaran Problem Based Learning (PBL). Model Pembelajaran PBL ini ditemukan pertama kali oleh ahli kesehatan di McMaster University di kanada pada tahun 1960-an. Idenya pertama kali muncul karena para siswa tidak mampu menerapkan sejumlah pengetahuan ilmiah dasar untuk situasi klinis. Pembelajaran berbasis masalah ini membuat siswa menjadi pembelajar yang mandiri, artinya ketika siswa belajar, maka siswa dapat memilih strategi belajar yang sesuai, terampil menggunakan strategi tersebut untuk belajar dan mampu mengontrol proses belajarnya serta termotivasi untuk menyelesaikannya (Kurniasih dan Sani 2015: 48). PBL adalah "model pembelajaran yang berdasar pada masalah-masalah yang dihadapi siswa terkait dengan KD yang sedang dipelajari siswa" (kosasih 2014:88). PBL adalah "model pengajaran yang bercirikan adanya permasalahan nyata sebagai konteks untuk para peserta didik belajar berpikir kritis dan keterampilan memecahkan masalah serta memperoleh pengetahuan" (Aris Shoimin 2014 : 130). Tujuan PBL“bukanlah penyampaian sejumlah besar pengetahuan kepada peserta didik, melainkan berorientasi pada pengembangan kemampuan berfikir kritis dan kemampuan pemecahan masalah dan skaligus mengembangkan kemampuan peserta didik untuk secara aktif membangun pengetahuan diri" (Farhurrohman 2015:214). Menurut Afriana (2016) Model PjBL adalah sebuah model pembelajaran yang menggunakan proyek (kegiatan) sebagai inti pembelajaran. Pembelajaran $\mathrm{PjBL}$ terbukti dapat meningkatkan kreativitas siswa. Menurut Wajdi (2017) Project Based Learning memberikan pengalaman belajar yang detail, rinci, 
menantang, dan dalam jangka waktu yang lebih panjang dengan target terselesaikannya proyek yang menghasilkan sebuah produk, karya siswa yang memuaskan. Dengan sudut pandang yang sedikit berbeda Baron (1998, p.271) seperti dikutip Lindawati, Fatmariyanti, dan Maftukhin, 2013, p.43) berpendapat bahwa project based learning adalah suatu pendekatan pembelajaran yang membenturkan siswa kepada masalahmasalah praktis melalui stimulus dalam belajar. Peranan guru sangat penting dalam memberikan stimulus-stimulus agar siswa dapat melakukan pembelajaran secara mandiri, menemukan pemahamannya sendiri dan mengembangkan kreatifitasnya secara kolaboratif. Menurut Rais (2010) Project Based Learning merupakan sebuah model pembelajaran yang sudah banyak dikembangkan di negara-negara maju seperti Amerika Serikat. Jika diterjemahkan dalam bahasa Indonesia, Project Based Learning (PBL) bermakna sebagai pembelajaran berbasis proyek. Menurut Nafiah (2014) PBL merupakan suatu pendekatan pembelajaran yang menggunakan masalah dunia nyata sebagai suatu konteks bagi peserta didik untuk belajar tentang cara berpikir kritis dan keterampilan pemecahan masalah, serta untuk memperoleh pengetahuan dan konsep yang esensial dari materi pelajaran. PBL merupakan pembelajaran berdasarkan teori kognitif yang didalamnya termasuk teori belajar konstruktivisme. Menurut teori konstruktivisme, keterampilan berpikir dan memecahkan masalah dapat dikembangkan jika peserta didik melakukan sendiri, menemukan, dan memindahkan kekomplekan pengetahuan yang ada.

Berdasarkan hasil paparan di atas, maka dapat disimpulkan model pembelajaran PBL ini didahului dengan mengajukan permasalahan yang bersifat terbuka kepada siswa. Kemudian mereka diarahkan untuk melakukan penelitian secara kelompok dan diharapkan siswa lebih banyak memperoleh sutau keterampilan daripada pengetahuan yang hanya berupa hafalan. Mulai dari keterampilan memecahkan masalah, keterampilan berfikir kritis, keterampilan bekerja dalam kelompok, keterampilan interpersonal dan komunikasi, serta keterampilan pencarian dan pengelolaan informasi yang akan meningkatkan hasil belajar siswa. Oleh karena itu model pembelajaran PBL dapat diterapkan dalam pembelajaran di SD pada pembelajaran PKn.

Pendidikan kewarganegaraan (PKn) merupakan "mata pelajaran yang memfocuskan pada pembentukan warga negara yang memahami dan mampu melaksanakan hak-hak dan kewajibannya untuk menjadi warga negara Indonesia yang cerdas, terampil, dan berkarakter yang diamanatkan oleh pancasila dan UUD 1945" (Zubaedi 2011: 280). Menurut Undangundang Nomor 2 tahun 1989 menyebutkan bahwa pendidikan kewarganegaraan merupakan "usaha untuk membekali peserta didik dengan pengetahuan dan kemampuan dasar berkenaan dengan hubungan antar warga negara dengan negara serta pendidik pandahuluan Bela negara". Sedangkan menurut UU Sisdiknas yang baru yaitu UU No.20 Tahun 2003, pada penjelasannya pasar 37 dijelaskan bahwa Pendidikan Kewarganegaraan dimaksudkan "untuk membentuk peserta didik menjadi manusia yang memiliki rasa kebangsaan dan cinta tanah air 2003 : 66" (Sutoyo $2011: 6$ ). Pendidikan kewarganegaraan adalah "tentang hubungan antara warganegara dan negara serta pendidikan pendahuluan Bela Negara". Dalam pelaksanaannya selama ini, pada jenjang pendidikan dasar sampai dengan pendidikan menengah, pendidikan kewarganegaraan digabung dengan Pendidikan Pancasila menjadi Pendidikan Pancasila dan Kewarganegaraan (PKn) (Sumayasa 2017). Pendidikan kewarganegaraan (PKn) adalah muatan materi yang digunakan sebagai wahana untuk mengembangkan dan melestarikan nilai luhur dan moral yang berakar pada budaya bangsa Indonesia (Widyasari 2016).

Dengan demikian, maka dapat disimpulkan pendidikan kewarganegaraan adalah muatan materi sebagai wahana untuk mengembangkan dan melestarikan nilai luhur. Hal ini akan mudah tercapai jika nilai norma tetap di tanamkan pada siswa sejak usia dini, karena jika siswa sudah meliliki nilai norma yang baik, maka tujuan untuk mencapai warga Negara yang baik akan mudah terwujud, untuk itu perlunya PKn diajarkan di SD ialah agar siswa mampu melaksanakan hak-hak dan kewajiban sebagai warga Negara indonesiayang cerdas, trampil, berkarakter yang diamanatkan oleh pancasila dan UUD 1945, dan memhami nilai-nilai kedisiplina, kejujuran, serta sikap yang baik terhadap sesamanya, lawan jenisnya maupun terhadap orang yang lebih tua. Dari muatan materi PKn di sekolah dasar, PKn merupakan suatu muatan materi yang melatih penalaran peserta didik. Melalui muatan materi PKn di harapkan 
peserta didik dapat memiliki kompetensi untuk mengembangkan keterampilan serta memecahkan masalah.

Penilain merupakan "komponen penting dalam penyelenggaraan pendidikan". Upaya meningkatkan kualitas pendidikan dapat ditempuh melalui peningkatan kualitas pembelajaran dan kualitas sistem penilainnya. Keduanya saling terkait, sistem pembelajaran yang baik akan menghasilkan kualitas belajar yang baik. Kualitas pembelajaran ini dapat dilihat dari hasil penilaian (Harum Rasyid 2007:6).

Penilaian proyek merupakan "penilaian terhadap suatu tugas yang harus deselesaikan dalam periode/waktu tertentu". Tugas tersebut berupa suatu investigasi sejak perencanaan, pengumpulan data, pengorganisasian, pengelahan, dan penyajian data (B. Uno, dan Koni 2012 : 24). Penilaian proyek merupakan "kegiatan penilaian terhadap suatu tugas yang meliputi: pengumpulan, pengorganisasian, pengevaluasian, dan penyajian data yang harus diselesaikan dalam waktu atau periode tertentu" (Kunandar 2015:286). Penilaian proyek merupakan "kegiatan penilaian terhadap suatu tugas yang harus diselesaikan dalam periode/waktu tertentu" (Agung 2010:95). Dengan demikian, maka dapat disimpulkan bahwa penilaian proyek adalah penilaian yang dilakukan dengan jangka waktu tertentu, melalui pemberian tugas kepada siswa berupa proyek yang lebih menitik beratkan pada penilaian proses. Proyek ini adalah suatu cara yang sangat bagus untuk melibatkan siswa dalam situasi pemecahan masalah yang luas.

Berdasarkan hasil observasi dan wawancara pada siswa kelas IV sekolah dasar gugus VI Tegallalang, ditemukan bahwa penguasaan kompetensi pengetahuan PKn siswa belum optimal. Hal tersebut dilihat dari persentase jumlah siswa yaitu dari 164 siswa kelas IV, 8 siswa yang mendapat nilai $A, 91$ siswa yang mendapat nilai $B, 35$ siswa yang mendapat nilai $C, 23$ siswa yang mendapat nilai D. Berdasarkan data yang diperoleh 58 siswa yang nilai kompetensi pengetahuan PKn masih berada di bawah Ketuntasan Minimal (KKM) dengan KKM untuk kompetensi pengetahuan PKn di kelas IV sekolah dasar gugus VI Tegallalang adalah 70.

Berdasarkan uraian yang telah di paparkan maka dilakukan suatu penelitian yang berjudul "Pengaruh Model Pembelajaran Problem Based Leraning Berbantuan Penilaian Proyek Terhadap Kompetensi Pengetahuan PKn Siswa Kelas IV Gugus VI Tegallalang.

\section{Metode}

Penelitian ini dilaksanakan pada semester 2 tahun ajaran 2017/2018 di kelas IV SD Gugus VI Tegallalang. Penelitian ini bertujuan untuk mengetahui perbedaan kompetensi pengetahuan PKn antara kelompok siswa yang dibelajarkan dengan model pembelajaran PBL berbantuan Penilaian Proyek dengan kelompok siswa yang dibelajarkan dengan pembelajaran konvensional (pendekatan saintifik). Rancangan penelitian yang digunakan Quasi Eksperimen dengan rancangan Nonequivalent Control Grup Design. Dalam penelitain ini yang di bandingkan adalah skor post-test siswa. Populasi dari penelitian ini adalah seluruh siswa kelas IV (Empat) SD Gugus VI Tegallalang tahun pelajaran 2017/2018, yang terdiri dari 5 kelas dalam 5 sekolah dasar. Jumlah populasi dari penelitian ini adalah 164 orang. Berdasarkan hasil wawancara dengan Kepala Sekolah dan Wali Kelas IV di SD Gugus VI Tegallalang, diperoleh informasi bahwa kelas IV Gugus VI Tegallalang, masing-masing individu dalam kelas tiap sekolah setara karena disebar secara merata antara siswa yang memiliki kemampuan tinggi, sedang dan rendah. Hal tersebut berarti tidak terdapat kelas unggulan maupun non unggulan.

Teknik pengambilan sampel pada penelitian ini adalah Random Sampling yang dirandom kelasnya, sehingga setiap kelas mendapatkan peluang yang sama untuk menjadi sampel penelitian. Pemilihan sampel penelitian ini tidak dilakukannya pengacakan individu melainkan hanya pengacakan kelas. Setelah dilakukan pengundian diperoleh kelas IV SD Negeri 2 Keliki yang berjumlah 34 siswa sebagai kelas Eksperiment dan kelas IV SD Negeri 1 Keliki yang berjumlah 35 siswa sebagai kelas Kontrol. Selanjutnya, dilakukan penyetaraan terhadap kedua sampel tersebut. Teknik yang digunakan dlam ini adalah teknik matching. "Matching adalah suatu teknik untuk menyeragamkan kelompok pasa suatu variabel atau lebih yang sudah 
diidentifikasi mempunyai hubungan yang erat dengan penampilan (performance) variabel tidak bebas". Darmadi (2014:235).

Metode pengumpulan data yang digunakan dalam penelitian ini ialah denagn metode tes. Tes yang digunakan pada penelitian ini adalah tes obyektif. Penguasaan kompetensi pengetahuan PKn siswa yang diperoleh dari test. Sebelum memberikan tes kepada siswa, maka dilakukan pengujian untuk menguji kelayakan instrumen. Tes yang baik harus memenuhi syarat ketepatan (validitas) dan keajegan (reliabilitas). Untuk itu, sebelum tes tersebut digunakan, terlebih dahulu tes di uji validitas, reliabilitas, daya pembeda dan tingkat kesukaran.

Pada penelitian ini, digunakan dua teknik analisis yaitu analisis statistic deskriptif dan statistik inferensial. Statistic deskriptif salam penelitian digunakan untuk mengetahui mean, standar deviasi, dan varians.

\section{Hasil dan Pembahasan}

Berdasarkan analisis data dilakukan setelah kelompok eksperiment diberikan perlakuan model pembelajaran PBL Berbantuan Penilaian Proyek dan kelompok kontrol dengan pembelajaran Konvensional, sebanyak enam kali pertemuan dengan materi ajar yang sama. Analisis data dilakukan pada masing-masing kelas yaitu kelas eksperiment dan kelas Kontrol. Berdasarkan hasil analisis diperoleh harga $X^{2}$ hitung $=5,99$ untuk kelompok eksperimen. Harga tersebut kemudian dikonsultasikan dengan harga $X^{2}$ tabel dengan $\mathrm{dk}=5$ dan tarif signifikan $5 \%$ sehingga diperoleh harga $X^{2}$ tabel $=11,070$. Karena $X^{2}$ hitung $=5,99 \leq X^{2}$ tabel $=11,070$ maka $\mathrm{H}_{0}$ dierima (gagal ditolak). Ini berarti sebaran data kompetensi pengetahuan PKn kelompok eksperimen berdistribusi normal. Sedangkan pada kelompok kontrol harga $X^{2}$ hitung $=5,23$ untuk kelompok kontrol. Harga tersebut kemudian dikonsultasikan dengan harga $X^{2}$ tabel dengan $\mathrm{dk}=5$ dan tarif signifikan $5 \%$ sehingga diperoleh harga $X^{2}$ tabel $=11,070$. Karena $X^{2}$ hitung $=5,23 \leq X^{2}$ tabel $=11,070$ maka $H_{0}$ dierima (gagal ditolak). Ini berarti sebaran data kompetensi pengetahuan PKn kelompok kontrol berdistribusi normal.

Uji homogenitas varians data kompetensi pengetahuan PKn kelompok eksperimen dan kelompok kontrol di peroleh $\mathrm{F}_{\text {hitung }}=1,56$. Nilai tersebut kemudian dikonsultasikan dengan harga $F_{\text {tabel }}$ dengan taraf signifikan 5\% dengan derajat kebebasan (dk1) untuk pembilang $\mathrm{n} 1-1=$ 31-1 dan derajat kebebasan ( $d k 2$ ) untuk penyebut $n 2-1=31-1$. Dan hasil analisis $F_{\text {tabel }}=1,84$, karena $F_{\text {hitung }} 1,74 \leq F_{\text {tabel }}$ 1,84 maka dapat dikatakan data kompetensi pengetahuan PKn kelompok eksperimen dan kelompok kontrol mempunyai varians yang homogen.

Berdasarkan hasil uji normalitas sebaran data dan uji homogenitas varians dapat diketahui bahwa data yang diperoleh dari kelompok eksperimen dan kelompok kontrol berdistribusi normal dan memilki varians yang homogen. Karena data yang diperoleh telah memenuhi uji prasyarat analisis, maka uji hipotesis dapat dilakukan dengan menggunakan analisis uji-t. Pengujian hipotesis dengan uji-t dari data kompetensi pengetahuan PKn siswa

Dari hasil analisis diperoleh $t_{\text {hitung }}=5,547$ dan $t_{\text {tabel }}=2,000$ pada taraf signifikansi $5 \%$ dengan $\mathrm{dk}=\mathrm{n} 1+\mathrm{n} 2-2=(31+31-2)=60$. Oleh karena $\mathrm{t}_{\text {hitung }} 5,547>\mathrm{t}_{\text {tabel }} 2,000$ maka $\mathrm{H}_{0}$ yang menyatakan tidak terdapat perbedaan yang signifikan kompetensi pengetahuan PKn kelompok siswa yang dibelajarkan melalui model pembelajaran PBL berbantuan penilaian proyek dengan kelompok siswa yang dibelajarkan melalui pembelajaran konvesional pada kelas IV SD Negeri Gugus VI Tegallalang tahun pelajaran 2017/2018 di tolak dan $\mathrm{H}_{\mathrm{a}}$ yang menyatakan bahwa terdapat perbedaan yang signifikan kompetensi pengetahuan PKn kelompok siswa yang dibelajarkan melalui model pembelajaran PBL berbantuan penialain proyek dengan kelompok siswa yang dibelajarkan melalui pembelajaran konvesional pada kelas IV SD Negeri Gugus VI Tegallalang tahun pelajaran 2017/2018 diterima.

Perolehan hasil perhitungan analisis data yang dilakukan terhadap kelompok eksperimen dan kelompok kontrol, menunjukkan bahwa nilai rerata siswa yang dibelajarkan menggunakan model pembelajaran PBL berbasntuan penilaian Proyek $(\bar{X}=83,02)$ dengan perolehan nilai terendah 60 dan nilai tertinggi 94, sesuai dengan analisis nilai kompetensi pengetahuan PKn siswa pada kelompok eksperimen. Hasil rata-rata siswa yang dibelajarkan menggunakan 
pembelajaran konvensional ( $\bar{X}=73,09$ ) dengan perolehan nilai terendah 54 dan nilai tertinggi 83, sesuai dengan analisis nilai kompetensi pengetahuan PKn siswa pada kelompok kontrol.

Hasil perolehan rata-rata kelompok eksperimen dan kelompok kontrol memiliki perbedaan sebesar 9,93. Dari hasil analisis diketahui bahwa sebaran data kompetensi pengetahuan PKn siswa berdistribusi normal dan memiliki varians yang homogen. Dari hasil analisis diperoleh $t_{\text {hitung }}=5,547$ dan $t_{\text {tabel }}=2,000$ pada taraf signifikansi $5 \%$ dengan $\mathrm{dk}=\mathrm{n} 1+\mathrm{n} 2-2=(31+31-2)=$ 60. Oleh karena $t_{\text {hitung }} 5,547>t_{\text {tabel }} 2,000$ maka $\mathrm{H}_{0}$ yang menyatakan tidak terdapat perbedaan yang signifikan kompetensi pengetahuan PKn antara siswa kelas IV SD Negeri Gugus VI Tegallalang tahun pelajaran 2017/2018 yang dibelajarkan mengggunakan model pembelajaraan PBL berbantuan Penilaian Proyek dan yang dibelajarkan menggunakan pembelajaran konvensional di tolak dan $\mathrm{H}_{\mathrm{a}}$ yang menyatakan bahwa terdapat perbedaan yang signifikan kompetensi pengetahuan PKn antara siswa kelas IV SD Negeri Gugus VI Tegallalang tahun pelajaran 2017/2018 yang dibelajarkan mengggunakan model pembelajaraan PBL berbantuan Penilaian Proyek dan yang dibelajarkan menggunakan pembelajaran konvensional diterima. Hal ini berarti terdapat perbedaan yang signifikan kompetensi pengetahuan PKn kelompok siswa yang dibelajarkan melalui model pembelajaran PBL berbantuan Penilain Proyek dengan kelompok siswa yang dibelajarkan melalui pembelajaran konvesional pada kelas IV SD Negeri Gugus VI Tegallalang tahun pelajaran 2016/2017.

Adanya perbedaan yang signifikan menunjukan bahwa model pembelajaran PBL berbantuan Penilaian Proyek berpengaruh terhadap kompetensi pengetahuan PKn siswa. Pengaruh model pembelajaran PBL berbantuan Penilaian Proyek berpengaruh terhadap kompetensi pengetahuan PKn dilihat dari perbedaan hasil analisis statistik deskriptif kedua kelompok sampel. Secara deskriptif rata-rata kompetensi pengetahuan PKn siswa kelompok eksperimen $\bar{X}=83,02$ dibandingkan dengan rata-rata kompetensi pengetahuan PKn kelompok kontrol $\bar{X}=73,09$. Jadi kompetensi PKn kelompok eksperimen $\bar{X}=83,02>\bar{X}=$ 73,09 kelompok kontrol.

Perbedaan yang signifikan kompetensi pengetahuan PKn siswa yang menggunakan model pembelajaran PBL berbantuan Penilaian Proyek dan pembelajaran secara konvensional dapat disebabkan oleh karena kelas eksperimen kegiatan pembelajaran dalam muatan materi PKn menggunakan model pembelajaran PBL berbantuan Penilaian Proyek berjalan dengan optimal dan kondusif. Pembelajaran dengan model Pembelajaran PBL berbantuan Penilaian Proyek secara tidak langsung telah menumbuhkan minat belajar siswa yang masih sangat kurang saat ini. Model pembelajaran PBL berbantuan Penilaian Proyek akan membuat siswa lebih aktif dalam pembelajaran serta lebih menarik karena siswa akan terlibat langsung dalam pembelajaran. (kosasih 2014:88). PBL adalah "model pembelajaran yang menggunakan masalah nyata (autentik) yang tidak terstruktur dan bersifat terbuka sebagai konteks bagi peserta didik untuk mengembangkan keterampilan menyelesaikan masalah dan berfikir kritis serta sekaligus membangun pengetahuan baru". Berbeda pada kelompok kontrol, kegiatan pembelajaran konvensional yang hanya menggunakan pendekatan saintifik berjalan kurang optimal. Hal ini disebabkan masih siswa yang kurang mampu mengaitkan antar materi pada muatan materi PKn dan kesulitan mengikuti setiap langkah pembelajaran yang perlu diberikan bimbingan lebih khusus. Pembelajaran menggunakan model pembelajaran PBL berbantuan penilaian proyek pada muatan materi PKn memberikan kesempatan yang lebih luas kepada siswa untuk mengonstruksikan pengetahuannya melalui berbagai kegiatan bermakna dan teratur yang tentunya menggembirakan bagi siswa pada setiap langkah pembelajarannya. Dengan demikian, perbedaan hasil kompetensi pengetahuan PKn dapat terlihat dari langkah pembelajaran yang dilakukan pada kedua kelompok tersebut, hasil analisis uji hipotesis, dan nilai rerata kelompok siswa yang mengikuti pembelajaran menggunakan model pembelajaran PBL berbantuan penilaian proyek dengan siswa yang mengikuti pembelajaran konvensional.

Hasil penelitian ini memperkuat simpulan yang disampaikan oleh Sumayasa (2017) bahwa terdapat perbedaan hasil belajar PKn siswa yang dibelajarkan dengan model PBL dan kelompok siswa yang dibelajarkan dengan model pembelajaran konvensional. 
Berdasarkan paparan tersebut, dapat dikatakan bahwa model pembelajaran PBL berbantuan Penilaian Proyek berpengaruh terhadap kompetensi pengetahuan PKn siswa kelas IV SD Negeri Gugus VI Tegallalang tahun pelajaran 2017/2018.

\section{Simpulan dan Saran}

Berdasarkan hasil analisis data kompetensi pengetahuan PKn pada kelompok eksperimen terdapat 31 siswa dengan nilai tertinggi yang diperoleh 94 dan nilai terendah adalah 60. Dari sebaran data tersebut diperoleh data yang paling sering rata-rata (mean) adalah 83,02 Baik.

Berdasarkan hasil analisis data kompetensi pengetahuan PKn pada kelompok kontrol terdapat 31 siswa dengan nilai tertinggi yang diperoleh 83 dan nilai terendah adalah 54. Dari sebaran data tersebut diperoleh data yang paling sering rata-rata (mean) adalah 73,12 Cukup.

Dari hasil analisis diketahui bahwa sebaran data kompetensi pengetahuan PKn siswa berdistribusi normal dan memiliki varians yang homogen. Dari hasil analisis diperoleh $t_{\text {hitung }}=$ 5,547 dan $t_{\text {tabel }}=2,000$ pada taraf signifikansi $5 \%$ dengan $\mathrm{dk}=\mathrm{n} 1+\mathrm{n} 2-2=(31+31-2)=60$. Oleh karena $t_{\text {hitung }} 5,547>\mathrm{t}_{\text {tabel }} 2,000$ maka $\mathrm{H}_{0}$ yang menyatakan tidak terdapat perbedaan yang signifikan kompetensi pengetahuan PKn kelompok siswa yang dibelajarkan melalui model pembelajaran PBL berbantuan Penilaian Proyek dengan kelompok siswa yang dibelajarkan melalui pembelajaran konvesional pada kelas IV SD Negeri Gugus VI Tegallalang tahun pelajaran 2017/2018 di tolak dan $\mathrm{H}_{a}$ yang menyatakan bahwa terdapat perbedaan yang signifikan kompetensi pengetahuan PKn kelompok siswa yang dibelajarkan melalui model pembelajaran PBL berbantuan Penilaian Proyek dengan kelompok siswa yang dibelajarkan melalui pembelajaran konvesional pada kelas IV SD Negeri Gugus VI Tegallalang tahun pelajaran 2017/2018 diterima. Dilihat dari rata-rata kelompok siswa yang dibelajarkan melalui model pembelajaran PBL berbantuan Penilaian Proyek $\bar{X}=83,02>\bar{X}=73,09$ kelompok siswa yang dibelajarkan secara konvensional. Jadi dapat disimpulkan bahwa model pembelajaran PBL berbantuan Penilaian Proyek berpengaruh terhadap kompetensi pengetahuan PKn siswa kelas IV SD Negeri Gugus VI Tegallalang tahun pelajaran 2017/2018

Ada bebrapa saran yang dapat diajukan berdasarkan temuan dan kajian penelitian ini adalah sebagai berikut: 1) Kepada Guru Berdasarkan temuan penelitian yang diperoleh, disarankan kepada guru agar lebih kreatif untuk memberikan fasilitas berupa sumber belajar dan kesempatan yang lebih besar bagi siswa pada pembelajaran dengan menggunakan model pembelajaran PBL berbantuan Penilaian Proyek dan dapat dijadikan alternatif dalam proses pembelajaran untuk membantu peserta didik meningkatkan kompetensi pengetahuan PKn dengan maksimal. 2) KepadaSekolah Berdasarkan temuan penelitian, disarankan kepada kepala sekolah agar dapat menggunakan hasil penelitian ini sebagai sebagai alternatif dalam mengelola pembelajaran agar sesuai dengan karakteristik pembelejaran PKn, sehingga mampu meningkatkan pengetahuan dan pemahaman peserta didik tentang PKn. 3) Kepada Peneliti lain Berdasarkan temuan penelitian,disarankan kepada peneliti agar hasil penelitian ini digunakan sebagai suatu acuan bagi peneliti lain untuk mengembangkan kemampuan diri dalam mempersiapkan diri sebagai calon pendidik dan meningkatkan pemahaman mengenai kurikulum 2013 dengan penerapan model pembelajaranPBLberbantuanPenilaian Proyek.

\section{Daftar Rujukan}

Afriana, J., dan Fitriani, A. 2016. "Penerapan Project Based Learning Terintegrasi STEM Untuk Meningkatkan Literasi Sains Dan Kreativitas Siswa Ditinjau Dari Gender". Jurnal Inovasi Pendidikan IPA, 2(2): 202-212.

Aris Shoimin 2014. 68 model pembeljaran inovatif dalam kurikulum 2013, Yogyakarta, Ar-ruz Medi. 
Depdiknas 2013. Permendikbud Nomor 81A Tahun 2013. Jakarta: Kementrian Pendidikan dan Kebudayaan.

Depdiknas 2013. Permendikbud Nomor 57 Tahun 2014 Lampiran 1. Jakarta: Kementrian Pendidikan dan Kebudayaan..

Hamzah B. Uno dan Satria Koni. Assessment pembelajaran, Jakarta, Bumi Akasa, 2012.

Lindawati, F., Siska D., \& Maftukhin, A. (2013). Penerapan model pembelajaran project based learning untuk meningkatkan kreativitas siswa MAN I Kebumen. Jurnal Radiasi, Vol. 3, (1). HIm. 42-45.

Rais, M. (2010). Project based learning: inovasi pembelajaran yang berorientasi soft skills. Makalah dalam Seminar Nasional Pendidikan Teknologi dan Kejuruan Fakultas Teknik Universitas Negeri Surabaya 11 Desember 2010.

Sugiyono. 2012. Metode Penelitian Kuantitatif Kualitatif dan R\&D. Bandung: Alfabeta.

Muhammad Fathurrohman 2015. Para Digma Pembelajaran Kurikulum 2013, Strategi Alternatif Pembelajaran di Era Global.

Setyosari, Punaji. 2015. Metode Penelitian Pendidikan\&Pengembanga. Jakarta: Kencana Prenada Media Group.

Wajdi, Fathullah. 2017. Implementasi Project Based Learning (PBL) dan Penilaian Autentik dalam Pembelajaran Drama Indonesia. Jurnal Pendidikan Bahasa dan Sastra, Vol. 17, No. 1, April 2017, Hal. 81-97. 